\title{
School Students' Depictions of Mathematics Teaching and Learning Practices
}

\author{
Vesife Hatisaru*
}

\author{
Received \\ Revised \\ 4 August 2020 \\ Accepted \\ 8 October 2020 \\ $\mathrm{DO}$ \\ 10.26822/iejee.2021.184
}

Correspondance Details: Vesife Hatisaru.

School of Education, College of Arts, Law and Education, University of Tasmania, Launceston, Tasmania, Australia.

E-mail: Vesife.Hatisaru@utas.edu.au

ORCID: http://orcid.org/0000-0003-2101-1764

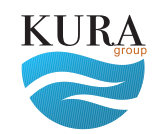

Copyright @

Www.iejee.com

ISSN: 1307-9298

C 2020 Published by KURA Education \& Publishing. This is an open access article under the CC BY- NC- ND license. (https://creativecommons. org/licenses/by/4.0/)

\begin{abstract}
The current study examined pictorial and written descriptions of mathematics teaching and learning among a cohort of 120 students (aged 11 to 14 years) in three different lower secondary schools in Ankara, Turkey. A classroom environment with students working in groups or pairs and engaging in open-ended questions or tasks was unavailable. The students viewed teaching of mathematics only as instruction and practicing, and that learning occurs when students sit at desks and passively listen to the teacher who stands in front of the class and explains and demonstrates the subject and/or solves routine questions. Implications for policy makers include the need to determine the contributors to students' current perceptions of mathematics teaching and learning experiences. Building positive perceptions relating to mathematics and mathematics learning experiences in students is a prerequisite to enabling students to develop mathematical proficiency.
\end{abstract}

\section{Keywords: \\ Draw a Mathematics Classroom Test, Mathematics practices, Mathematical tasks, Representations, School students}

\section{Introduction}

In a previous study, Hatisaru (e.g., 2019a, 2019b) investigated a large group of 1284 Turkish lower secondary school students' (aged 11 to 14) images of mathematics through examining their Draw a Mathematician Test (DAMT) (Picker \& Berry, 2000) depictions and associated descriptions. The students' drawings fell into two distinct groups: depicting a mathematician at work (Hatisaru, in press), or as a mathematics teacher in the classroom (Hatisaru, 2019a). Focusing on the latter group, Hatisaru (2019b) examined the modes of instruction in mathematics classrooms through the students' eyes. This analysis of student drawings and writing revealed that most students depicted, highly teacher-directed mathematics classrooms which relied heavily on the teacher lecturing, explaining, or solving 
exercises. The results, however, were limited to using students' drawings of mathematicians, and revealed a need for further investigations. In the present study, I explore the same age group students' perceptions of mathematics teaching and learning practices by examining their mathematics classroom pictures and associated texts. The research questions asked are, through the students' eyes, in mathematics classrooms: (1) What are the teaching practices of a teacher? (2) What are the learning practices of students? and (3) What materials and tools are used? Mathematical tasks (questions, expressions, equations) in students' pictures and their representational forms (e.g., symbolic, visual, verbal) are also of interest.

Mathematical capability is accepted as one of the key competences necessary for students' success in school and later in life (Smith \& Stein, 2011). Although globally students' mathematics performance has showed improvements, many school students still are not reaching the desirable mathematics performance benchmarks (Mullis, Martin, \& Loveless, 2016). There has been a stalled or declined mathematics performance in Turkish school students against international benchmarks (e.g., Mullis, Martin, Foy, \& Hooper, 2016), and a decline in the participation in tertiary mathematics courses (e.g., Nesin, 2015). This study's findings extend the knowledge of school students' perceptions of mathematics and its teaching and learning previously obtained from questionnaires (e.g., Mullis, Martin, Foy, \& Hooper, 2016). The students' pictorial and verbal reflections provide valuable insights which could be useful to understand for future development of mathematics provision in Turkey.

Below, the relevant literature that informed this research is critiqued before the context of the study is discussed. The research instrument is presented followed by the development of its corresponding coding schema and data analysis. Finally, the results of analysis, preliminary conclusions about the teaching and learning practices and resources used in mathematics classrooms seen through the students' eyes, and further research recommendations are presented.

\section{Relevant Literature}

\section{The Image of Mathematics}

The teacher and student activities depicted, occurring within a mathematics classroom underpins students' perceptions of their mathematics teaching and learning experiences and consequently their images of mathematics as represented in drawings. The image of mathematics construct is defined as the feelings, expectations, experiences and confidence individuals hold about mathematics (Brown, 1992), and is "understood broadly to include all visual and verbal representations, metaphorical images and associations, beliefs, attitudes and feelings related to mathematics and mathematics learning experiences" (Sam \& Ernest, 2000, p. 195). Lane, Stynes and O'Donoghue (2014) suggest that the image of mathematics is "a mental representation or view of mathematics, presumably constructed as a result of past experiences, mediated through school, parents, peers or society" (p. 881). In all current definitions, the image of mathematics is conceptualized as a multifaceted construct composed of several aspects. According to Sam and Ernest (2000), the image of mathematics is composed of, for instance: stated attitudes; feelings; descriptions or metaphors for learning mathematics; views about mathematicians and their work; and descriptions for mathematics learning experiences. To Lane et al. (2014), it involves attitudes, emotions, beliefs, motivation, and selfconcepts relating to mathematics and mathematics learning experiences.

Certain components of the image of mathematics involving attitudes towards and beliefs about mathematics have been widely investigated (e.g., Hatisaru \& Murphy, 2019; Johansson \& Sumpter, 2010; Markovits \& Forgasz, 2017). The research in the image of mathematics field still needs more information on the perceptions of students relating to their classroom teaching and learning experiences. Largescale assessments such as Trends in International Mathematics and Science Study (TIMSS) and Programme for International Student Assessment (PISA) have identified the perceptions of students in regards various aspects of school and classroom climate, but these studies are limited to responses gleaned from questionnaire items (Vieluf, Kaplan, Klieme, \& Bayer, 2012). The statements used in questionnaires are not necessarily understood by school students in the way researchers intended (Bragg, 2007). More detailed information about students' perceptions of mathematics teaching and learning experiences would help to alleviate some of the limitations in the existing literature. It would be also easier to assess the claims about students' performance in mathematics and/or images about mathematics, by reviewing evidence addressing students' perceived classroom experiences.

\section{Teaching and Learning Practices in Mathematics Classrooms}

The learning of mathematics has been defined as the achievement of five intertwined strands, which together constitute mathematical proficiency: conceptual understanding; procedural fluency; 
strategic competence; adaptive reasoning; and productive disposition (for details, see Kilpatrick, Swafford, \& Findell, 2001). In the alignment of the first four of these strands understanding, fluency, problemsolving, and reasoning in mathematics have been seen to represent the basis for mathematical proficiency (Australian Curriculum Assessment and Reporting Authority [ACARA], 2018). These proficiency strands have been variously described as the standards or the practices that students need to engage with during mathematics learning to become proficient in mathematics (ACARA, 2018; National Council of Teachers of Mathematics [NCTM], 2014). In the USA, these practices are called Common Core State Standards for Mathematics (CCSSM) and involve: making sense of problems and persevering in solving them; reaching viable arguments and critiquing the arguments of others; modelling with mathematics; and using appropriate tools strategically (National Governors Association Centre for Best Practices and Council of Chief State School Officers [NGA Centre and CCSSO], 2010).

The teaching that fosters mathematical proficiency can take a variety of forms. Kilpatrick et al. (2001) suggest that the effectiveness of teaching depend on, among other things, selecting cognitively demanding tasks and engaging students with learning tasks by using manipulatives representing mathematical ideas. Swan (2005) presents a set of principles that should underline all effective teaching practices. According to Swan (2005), teachers should use rich collaborative tasks because such tasks can promote discussion and communication, and when combined with the use of technology in appropriate ways, engage and motivate students. Anthony and Walshaw (2009) describe worthwhile mathematical tasks, making connections among mathematical ideas, mathematical communication, and the use of tools and representations as effective mathematics teaching practices. Bobis, Anderson, Martin, and Way (2011) present four strategies for teaching practices: variety in teaching approaches; real and relevant tasks; open-ended questions; and using errors as a focus for learning. The NCTM (2014) has developed a further phase of the education standards initiative, Principals to Actions: Ensuring Mathematical Success for All, and represents a set of research-informed mathematics teaching practices. A few are: implementing tasks that promote problem solving; using and connecting mathematical representations; and building procedural fluency from conceptual understanding.

The specific teaching practices that appear to be most common include, utilising rich open-ended tasks, selecting problems for which there are multiple methods of solution, using appropriate tools to explore those problems and deepen understanding of concepts, and giving students more active roles in the learning process.

\section{Using Drawings to Explore Students' Perceptions of Mathematics Practices}

Science education researchers (e.g., Chambers, 1983) have contributed much to the conceptualization and assessment of the drawing method, followed by mathematics education researchers. The historical beginnings of the drawing method in science education have been provided in Thomas, Pedersen and Finson (2001) and Finson (2002). Hatisaru (2019a) has reported the beginnings of adaptation of the drawing method to mathematics education. Here, a synthesis of research into utilising drawings to investigate students' mathematics classroom perceptions, with a focus of the method's validity, is presented.

The use of drawings as a measure of students' conceptions of teaching and learning has been found to be valid and useful (e.g., Gulek, 1999; Harris, Harnett, \& Brown, 2009; Hatisaru, 2019a; Laine, Ahtee, \& Növeri, 2020; Losh, Wilke, \& Pop, 2008), and a costeffective alternative to interviews and classroom observations (Haney, Russel, \& Bebell, 2004). Studies designed to validate whether students' depictions are representative of their actual classroom experiences, through incorporating teacher interviews and classroom observations (Remesal, 2009) or classroom video recordings (Laine et al., 2020), have found a close link between the student drawings and their actual classroom practices. Remesal (2009) reports that, "this awareness [of perceptions of classroom assessment practices] develops even though the teachers themselves might not believe 8-year olds are capable of such insights" (p. 47).

The drawing method offers more opportunities for students to express their core opinions about mathematics, and mathematics teaching and learning, than questionnaires (Stiles, Adkisson, Sebben, \& Tamashiro, 2008). Through this method, students are given control of the data collection process and can draw freely about their experiences of mathematics (Kearney \& Hyle, 2004). Student drawings therefore contain rich information on their thoughts about mathematics and its teaching and learning (Pehkonen, Ahtee, \& Laine, 2016). The drawing method has been widely used to elicit data from students regarding their image of science and mathematics in many countries and on different continents including in 
Europe, the Middle East, Asia, and the USA. In Hatisaru (2019a), an extensive review on past research using drawings to access various components of the images of mathematics held by school students is reported. In the following section, perceived mathematics teaching and learning practices found in student drawings are presented.

\section{Previous Research Findings}

Picker and Berry (2000) investigated the perceptions of mathematicians held by school students (12 to 13 years old) in the USA, the UK, Finland, Sweden, and Romania by using the DAMT and compared their images. The students' images were found to be common with small cultural differences. The students quite often pictured mathematicians as a mathematics teacher in the classroom and found getting the correct answer was the most important thing in mathematics lessons. The students' pictures frequently involved questions such as: "What's the answer? What is the result? What's going on here?" (p. 84). Most participant students' DAMT drawings were similarly shown in the classroom in another study in the USA (Rock \& Shaw, 2000). The students (kindergarten - grade 8) named tools that they were familiar with from their own classrooms (e.g., paper, pencils, whiteboards) as the tools of mathematicians. The second and third grade students mentioned calculators, rulers, geometric shapes, while fourth grade and middle school students expanded their responses to include computers, calculators, and protractors.

Johansson and Sumpter (2010) investigated grade 2 and 5 students' conceptions about mathematics and mathematics education revealed in their drawings in Sweden. Mostly positive attitudes about mathematics were found. The younger students viewed learning of mathematics as an individual activity, while the elder students narrowed down it to calculating. Pehkonen, Ahtee, Tikkanen, and Laine (2011) used drawings in Finland to reveal students' (8-9 years old) conceptions of mathematics and its teaching. Of 153 student drawings, every second drawing included indications of attitudes about mathematics such as: mathematics is nice; easy; dull; or difficult. A total of 102 drawings indicated a classroom environment where students in the picture were in action such as thinking, speaking, or discussing. Laine, Näveri, Ahtee, Hannula and Pehkonen (2013) further analyzed these drawings to study the kind of emotional atmosphere in a mathematics lesson that could be seen in the students' depictions. A positive emotional atmosphere was found in the most pictures. Pehkonen et al. (2016) examined the same student drawings to explore the types of work experienced during a mathematics lesson through the eyes of students. The types of work most frequently depicted were independent work (students work individually for solving problems from textbooks or given by the teacher) and work with the teacher in charge (the teacher teaches the whole class, or all students work on the same task). Group work (students working with classmates on a task) was less common in students' pictures. Remesal (2009) used drawings to explore how primary school students (7 to 8 years old) perceived assessment practices in the classroom, and how students' conceptions might be shaped by their actual classroom experiences in Spain. Two practicing teachers and their twelve students participated in the research. Interviews with the teachers and students, classroom observations, and students' drawings of mathematics classrooms were collected. The students perceived assessment practices as: "someone is to ask and someone is to respond,' 'someone is to show the work and someone is to mark the work,' 'grades are given and the parents are informed'" (p. 47).

Ucar, Piskin, Akkas, and Tasci (2010) used drawings to investigate elementary school students' (grades 6 to 8) beliefs about mathematics and mathematicians in Turkey. They found that the students associated mathematics predominantly with numbers, formulas, or computations, and believed that mathematicians could be (purely) needed for their computational skills. Being good at mathematics, meant to the students, finding a correct answer to questions, even if not necessarily understanding the questions. Hatisaru (2019a) found that many Turkish students pictured their former or current mathematics teacher teaching in the classroom as a mathematician at work. The students viewed that the main activity of teachers was solving mathematics practice questions. Further analysis (Hatisaru, 2019b) showed, in the students' pictures, the most common mode of instruction was direct teaching. No evidence of a student-centered mode of instruction existed. A whiteboard and/or books were the most frequent teaching resources in classroom portrayals, while physical manipulatives and technological tools were notably absent.

Although an extensive drawing-based research has been carried out concerning students' perceptions of mathematics classroom practices, little attention has been paid to the voice of students in Turkey. The existing DAMT research findings are limited to using students' drawings of mathematicians. Student drawings have not yet been utilized to my knowledge to investigate how students perceive the types of mathematical tasks and forms of representations used in the classroom. This study extends the current literature by providing: (1) an analysis of data from Turkish school students regarding their perceptions of teaching and learning experiences in mathematics 
classrooms; and (2) additional evidence with respect to students' perceptions of two key aspects of classroom practices: mathematical tasks and their representations.

\section{The Study}

\section{Context}

In Turkey, students attend lower secondary education for four years (grades 5 to 8, aged 10 to 15). Mathematics is taught as a mandatory and major subject during all level of schooling and is part of national end of lower and upper secondary education exams which students sit at the completion of the lower secondary and high school, respectively. Mathematical questions make up $22 \%$ of the questions for high school entrance exam and $33 \%$ of the questions for the university entrance exam (European Schoolnet, 2018). Teaching in schools is regulated by the national curriculum. The learning and teaching practices suggested by the curriculum are similar to those suggested by international research studies and curricula. The goals of the lower secondary school mathematics curriculum (Ministry of National Education [MoNE], 2018) for students include: developing and using mathematical literacy skills effectively; understanding mathematical concepts and using them in daily life; expressing their reasoning in problem solving processes; and representing the concepts in different representational forms (p. 9). The curriculum encourages teachers to embrace teaching strategies which are inclusive of students' individual differences in mathematics learning and highlights the need for students to be active in their learning. A few suggested mathematics teaching practices include: the use of manipulatives in introducing new concepts and assessments when available (e.g., number cards, base ten block, fraction tiles or real-life models); encouragement of students to express their thinking orally and communicate their thinking both individually and in groups; and making connections across mathematics topics and other disciplines when relevant (p. 13-14, translation by the author).

\section{Data Source and Generation}

Data was generated through the Draw a Mathematics Classroom Test (Hatisaru, 2020a), adapted from the DAMT (Picker \& Berry, 2000) and Draw a Science Teacher Test (DASTT) (Thomas et al., 2001), and Gulek's (1999) work on using drawings to examine the educational ecology of classrooms. The Draw a Mathematics Classroom Test focuses on the pedagogical and curricular elements of the classroom (Evans, Harvey, Buckley, \& Yan, 2009). The test combines drawings with written responses. It provides a rectangular area in which students are asked to draw a picture. A prompt of: "Think about teachers of mathematics and the kinds of things you do in mathematics classrooms. Draw a picture of your teacher teaching and yourself learning" is given. At the bottom of the sheet, the following prompts are given to get students to describe their drawing: "Look back at the drawing and explain your drawing so that anyone looking at it could understand what your drawing means. What is the teacher doing? What are the students doing? What materials and tools are they using?" The use of drawing tasks with an accompanying text adds rigor to the instrument as the information provided in the writing reduces the subjectivity effect in coding the drawings (Murphy, Delli, \& Edwards, 2004).

The data was collected at the beginning of 2018-2019 academic year. A sample of 400 students, in grades 6 to 8 (aged 11 to 14 years), enrolled in three different lower secondary schools (two public, one private) located in Ankara, participated in the data collection process under the auspices of school principals. The schools were co-educational metropolitan schools with a relatively middle socioeconomic population based on family income. The instrument was implemented in Turkish, by counseling teachers at a time set aside by the school for school counseling, as that was convenient for the schools and minimized disruption. Students took the task individually in about thirty minutes and were not given extra drawing materials. In each school, there were four to eight mathematics teachers, most could be called midcareer. In data analysis, a priori thematic saturation, referring to the degree to which pre-determined codes or categories being sufficiently replete with instances of data (Saunders et al., 2017) was employed. Of the 400 responses, 120 were analyzed (for more details, see Coding). Male $(n=61)$ and female $(n=54)$ students were almost equally represented across this sample, while the number of grade $7(n=40)$ and grade $8(n=$ 66) students were greater than the number of grade $6(n=12)$ students. Participants were designated by codes (e.g., S1, S2, S3 and so on).

\section{Data Analysis}

To analyze the drawings and associated written descriptions a deductive content analysis was used (Elo \& Kyngäs, 2007). Specifically, this required a process of becoming familiar with and making sense of the data. Firstly, I inspected students' pictures and read associated descriptions several times. As learning activities and tasks that are utilized in classrooms is part of teaching and learning practices, I decided to analyze also the latent (silent) content of 
students' responses. This content involved depictions of written mathematical work (formulas, questions, equations, or expressions) on the whiteboard, and their representational forms (e.g., symbolic, visual). With assistance of a graduate research assistant, the data was transcribed and documented using excel spreadsheets. A coding schema was used for data analysis (see below).

\section{Operationalization of the coding schema}

To decide the coding categories, I drew upon the DASTT Checklist (DASTT-C) (Thomas et al., 2001). The DASTT-C consisted of three sections: Teacher (the teacher's activity such as demonstrating or lecturing and the teacher's position such as head of the classroom), Students (students' activity such as passive information receiver, responding to the teacher, and the position of the students such as seated in rows), and Environment (elements typically found inside classrooms such as desks in rows, symbols of teaching like whiteboards and materials). Drawing on the DASTT-C and focusing on the elements that emerged in the students' drawings particular to this study, I identified three main categories of classroom practices in the depicted pictures and drafted a coding schema. They are: (1) Teaching practices which identified the depicted teacher's roles and activities, (2) Learning practices which involved the depicted students' roles and activities, and (3) Teaching resources which assessed the teaching materials and tools utilized in the classroom, involving the characteristics of mathematical tasks and their representational forms (see Table 1).

The meaning of categories was informed by the relevant literature. Variety in teaching methods is defined as blending teacher-directed methods (e.g., explanation, demonstration, questioning, giving examples) with student-centered approaches (e.g., group work, problem-solving, student presentations, open-ended tasks) (Bobis et al., 2011). The teacher activities regarding the former methods involve, telling students which questions to do or to work through practice exercises, while the latter ones involve students learning through discussing their ideas, or working in pairs or small groups (Swan, 2006). The teaching methods in student drawings include scenarios where student desks are in rows, the teacher is depicted at the blackboard/ teacher's desk, and teacher talk, if any, is lecturing or disciplining. These indicate a teacher-directed mode of instruction. Scenarios indicate a student-centered mode of instruction in pictures where student desks are clustered, students are working in groups, teacher talk, if any, invites discussion, students are engaged in an activity, and the teacher is with or nearby students (Gulek, 1999).
Variety in teaching resources is defined by implementing various types of tasks and utilizing different materials and tools in exploring mathematical concepts and processes. Such materials might involve digital tools, concrete manipulatives, worksheets, models, calculators, and videos (Bobis et al., 2011). The types of mathematical tasks can be categorized into four: tasks requiring practicing procedures (Procedural) (e.g., Can you solve $7 x+4=5 x+8$ ?); tasks requiring the use of models or representations (Representational) (e.g., Giving students cards depicting the same mathematical idea (polyhedron) in different representations (verbal, visual, pictorial) and asking them to match the cards to enable them to draw links between representations of the same concept); tasks drawing from realistic contexts (Contextual) (e.g., If one pre-paid card for downloading music offers 16 songs for $\$ 24$, and another offers 12 songs for $\$ 20$, which is the better buy?); and tasks enabling the use of different solution strategies (Open-ended) (e.g., On squared paper, draw as many different parallelograms as you can with an area of 12 square units) (Sullivan, 2011).

Mathematical tasks and ideas in teaching can be represented in five distinct types of representation systems: Visual; Symbolic; Verbal; Contextual; and Physical. (Lesh, Post, \& Behr, 1987). Visual representations refer to anything made by hand or generated by computer that represent concrete objects such as a graph, chart, tallies, or table. Symbolic representations include numbers, formulae, geometric concepts, and numerical or algebraic expressions. Verbal representations incorporate the specialized language required of mathematical domains (e.g., fractions, probability). Contextual representations refer to situations happening in the real world (e.g., using money in shopping), while physical representations include concrete objects or manipulatives (e.g., base ten blocks; protractors; geoboards) that are designed to give students opportunities to learn mathematical concepts by manipulating them (Johnson, 2015).

Drawing upon these theoretical framings provided by the research studies mentioned above, a draft coding schema was developed. The research assistant and I used the draft coding schema independently and coded thirty randomly selected drawings. We then checked how well the coding schema categories covered the data and discrepancies in each of our coding trials. Only minor discrepancies came up. Table 1 presents the coding schema categories and their descriptions, after a few adjustments. Namely, a sub-category (inviting open-ended discussions), in the draft, was removed from the coding schema as there was no reference to a teacher activity inviting students to an open-ended discussion. The Sullivan's (2011) categorization of mathematics tasks and Lesh et al.'s (1987) taxonomy of representation systems 
Table 1

Categories of the Coding Schema and their Descriptions

\begin{tabular}{|c|c|c|c|}
\hline Main category & Generic category & Sub-category & Description \\
\hline \multirow{5}{*}{ Teaching practices } & \multirow{3}{*}{ Teacher activity } & Disciplining & Disciplining the class, asking students to be quiet \\
\hline & & Instructing & $\begin{array}{l}\text { Instructing, demonstrating, explaining about mathe- } \\
\text { matics }\end{array}$ \\
\hline & & Solving/asking PQs & Solving or asking students to solve practice questions \\
\hline & \multirow[t]{2}{*}{ Teacher position } & Centrally located & $\begin{array}{l}\text { Head of class, standing in front of the class, pointing } \\
\text { to or writing on the whiteboard, nearby or sitting at } \\
\text { the teacher's desk }\end{array}$ \\
\hline & & With/nearby students & $\begin{array}{l}\text { With or nearby students, sitting in with students or } \\
\text { pairs, bending down }\end{array}$ \\
\hline \multirow{6}{*}{ Learning practices } & \multirow{3}{*}{ Student activity } & Watching/listening & Watching or listening to the teacher teaching \\
\hline & & $\begin{array}{l}\text { Responding/solving } \\
\text { practice questions }\end{array}$ & $\begin{array}{l}\text { Responding to the teacher asking answers for prac- } \\
\text { tice questions or solving practice questions }\end{array}$ \\
\hline & & $\begin{array}{l}\text { Working in groups/ } \\
\text { pairs }\end{array}$ & $\begin{array}{l}\text { Working in groups or pairs, engaging in an activity } \\
\text { collectively }\end{array}$ \\
\hline & \multirow{3}{*}{ Student position } & $\begin{array}{l}\text { At the desk/white- } \\
\text { board (alone) }\end{array}$ & $\begin{array}{l}\text { Only one student depicted, sitting at a desk or at the } \\
\text { whiteboard, or suggested by classroom furniture }\end{array}$ \\
\hline & & $\begin{array}{l}\text { At the desk and seat- } \\
\text { ed in rows }\end{array}$ & $\begin{array}{l}\text { More than one student, sitting in rows or suggested by } \\
\text { classroom furniture }\end{array}$ \\
\hline & & Seated in semi-circle & $\begin{array}{l}\text { More than one student, sitting in clusters or suggested } \\
\text { by classroom furniture }\end{array}$ \\
\hline \multirow{6}{*}{ Teaching resources } & \multirow[b]{2}{*}{ Materials and tool } & Standard & E.g., whiteboard, notebooks, textbooks, pencil \\
\hline & & Alternative & $\begin{array}{l}\text { E.g., digital tools, concrete manipulatives, models, } \\
\text { calculators, videos }\end{array}$ \\
\hline & $\begin{array}{l}\text { Mathematical } \\
\text { tasks }\end{array}$ & Procedural & $\begin{array}{l}\text { Tasks that give students opportunities to practice } \\
\text { procedures in a mathematics content domain }\end{array}$ \\
\hline & \multirow{3}{*}{ Representations } & Symbolic & Numbers, numerical/algebraic expressions/equations \\
\hline & & Visual & Depictions such as graphs, tables, diagrams \\
\hline & & Verbal & $\begin{array}{l}\text { Specialized language of mathematics regarding } \\
\text { mathematics content domains }\end{array}$ \\
\hline
\end{tabular}

were used to analyze the nature of mathematical tasks and their representational forms. The coding schema did not involve Representational, Contextual and Open-ended tasks, and Contextual and Physical representations as there was no reference to any of these tasks and representations. The available Mathematical tasks in pictures corresponded to Procedural type of tasks, while representational forms of tasks matched to Symbolic, and, in a few cases, to Visual or Verbal form. The Procedural sub-category composed of seven groups (see Table 3 in the Results section).

\section{Coding}

The research assistant and I used the coding schema and coded thirty random drawings to calculate the degree of agreement between us (McHugh, 2012), achieving $93.75 \%$ agreement. As a result of this high score, we shared the coding of the remaining drawings equally between us. Throughout the coding, we discussed issues, if any, that required further attention for consensus. The written narrative descriptions contributed to gaining a deeper understanding of what students had drawn and confirmed our interpretations of input in drawings. Each sub-category was coded in a dichotomous fashion, whether each of these elements seemed to be represented in drawings and/ or written descriptions or not: 1- There is indication; or O- No indication. When the drawing or writing was not clear enough to decide, we coded them as: NCNot clear. Some responses were coded in more than one category. This response: "Smart board, notebook, pencil" (\$108, grade 8, boy), for instance, was coded across Standard and Alternative materials and tools sub-categories. Three drawings were excluded as they did not include enough information.

As mentioned earlier, a priori thematic saturation was employed to gauge the degree to which predetermined codes or categories were sufficiently represented in the data (Saunders et al., 2017). Specifically, while coding we found that there was little variation in student responses. In many of the pictures and texts the same categories were present or not. After the eightieth drawing, we considered 
that the categories were adequately represented in the data. We continued to coding data for forty more drawings to ensure and confirm that there was no variety in the remaining drawings. As we began to see the same student depictions and descriptions repeatedly, we became confident that the categories were saturated and terminated the coding of the remaining drawings.

Two student responses are presented in Figure 1 to illustrate the coding. In S43's response: Instructing; Centrally located; Watching/listening; Sitting in rows; Standard; Procedural; and Symbolic, and in S58's response: Solving/asking practice questions; Centrally located; Responding/solving practice questions; Sitting in rows; and Standard, sub-categories were assigned with: 1- There is indication as they include references to them. In S58's response there is no explicit reference to mathematical tasks or their representational forms, therefore, these sub-categories were assigned with: 0 - No indication. The mathematical tasks $\left(5^{3} \cdot 4^{3}=\right.$ ? and $8^{3}: 8^{2}=$ ?) in S43's picture were grouped into Procedural (practice questions), as they seem to be practice exercises requiring use of procedural knowledge in a mathematical content (exponents).

\section{Results}

Table 2 shows the frequency of responses corresponding to coding schema categories for the whole sample. In this section the findings for teaching and learning practices, and teaching resources, found in the students' responses are described.

\section{Teaching and Learning Practices}

A great majority of responses included clear indications that the depicted teacher was transmitting mathematical facts and procedures to students. Figures 1 and 2 provide typical examples of student responses. In almost all responses (97.4\%), the teacher was portrayed as the head of class. They were mostly depicted in front of the class, pointing to (Figure 2, S19) or writing on the whiteboard (Figure 1, S43). In approximately $83 \%$ of the responses, teachers were pictured and described as instructing, demonstrating or explaining about mathematics, while in about $36 \%$ of responses as solving mathematics practice exercises or assigning students for finding answers to them (Figure 1, S58). The students' texts abounded with statements such as: "The teacher is explaining exponential numbers to students" (S8, grade 8, boy); "Our teacher is teaching to us and he asks to the ones who don't understand to stand up and explains to them. We use pencil, eraser, ruler, book, notebook. What we do is having a class. What the teachers does is lecturing" (\$85, grade 6, boy). None of the diagrams show the teacher standing or sitting with or near students. Neither was there a reference to a teacher activity inviting students to an open-ended discussion or having a collaborative activity with students.

Little variation was found in students' responses regarding learning experiences. In most responses (about 83\%) students were drawn as relatively passive: watching or listening the teacher who was delivering a mathematical content. In $26.5 \%$ of drawings, students were portrayed as being made by the

Figure 1

S43 and S58's Drawings and Texts of the Mathematics Classroom

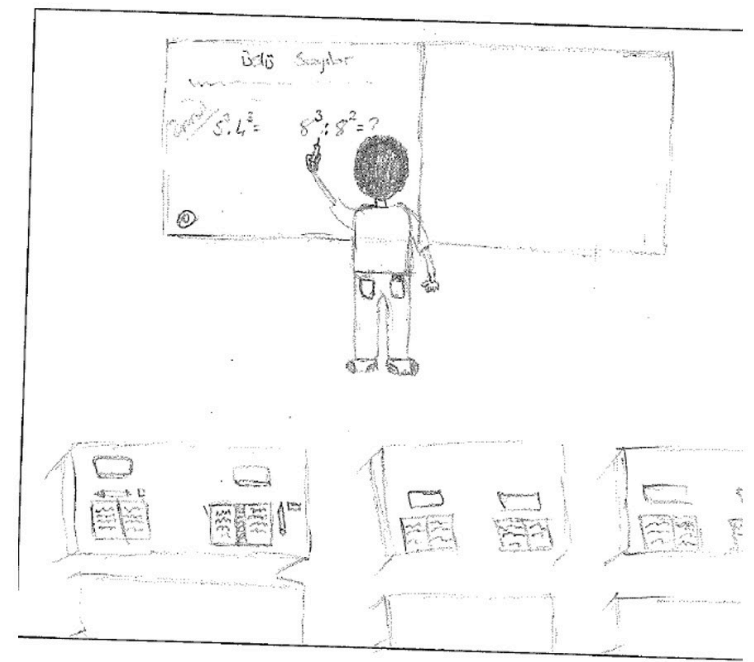

The mathematics teacher instructing the subject. Students are listening and taking notes. (S43, grade 8, girl)

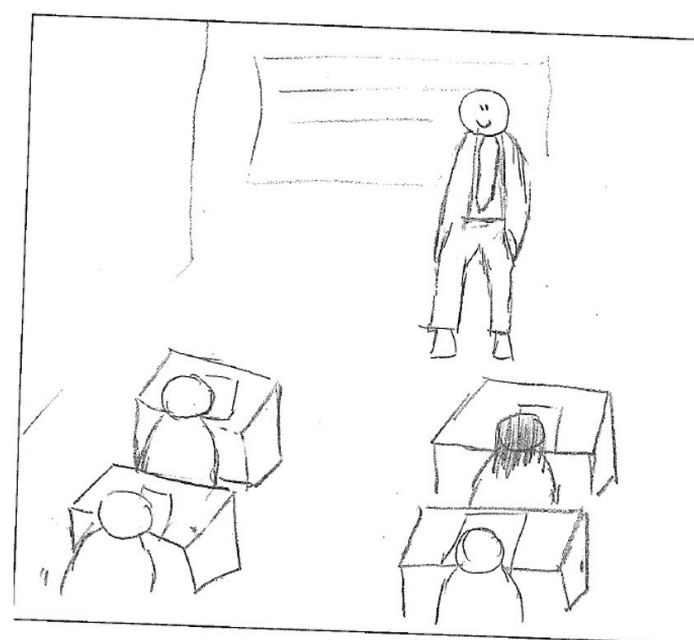

The teacher has assigned questions, students are solving the questions. (S58, grade 8 , girl) 
Table 2

Students' Responses Corresponded to the Coding Schema Categories ( $N=117)$

\begin{tabular}{|c|c|c|c|}
\hline Main category & Generic category & Sub-category & Level of inclusion: ' 1 ' \\
\hline \multirow{5}{*}{ Teaching practices } & \multirow{3}{*}{ Teacher activity } & Disciplining & $5(4.3 \%)$ \\
\hline & & Instructing & $97(82.9 \%)$ \\
\hline & & Solving/asking PQs & $42(35.9 \%)$ \\
\hline & \multirow{2}{*}{ Teacher position } & Centrally located & $114(97.4 \%)$ \\
\hline & & With/nearby students & - \\
\hline \multirow{6}{*}{ Learning practices } & \multirow{3}{*}{ Student activity } & Watching/listening & $97(82.9 \%)$ \\
\hline & & Responding/solving PQs & $31(26.5 \%)$ \\
\hline & & Working in groups/pairs & - \\
\hline & \multirow{3}{*}{ Student position } & At the desk/board (alone) & $64(54.7 \%)$ \\
\hline & & At the desk, seated in rows & $43(36.8 \%)$ \\
\hline & & Seated in semi-circle & $8(6.8 \%)$ \\
\hline \multirow{6}{*}{ Teaching resources } & \multirow{2}{*}{ Materials and tools } & Standard & $113(96.6 \%)$ \\
\hline & & Alternative & $8(6.8 \%)$ \\
\hline & Mathematical tasks & Procedural & $94(80.3 \%)$ \\
\hline & \multirow{3}{*}{ Representations } & Symbolic & $85(72.6 \%)$ \\
\hline & & Visual & $3(2.6 \%)$ \\
\hline & & Verbal & $2(1.7 \%)$ \\
\hline
\end{tabular}

teacher to find answers for practice questions (Figure 2, S63) or practicing mathematics exercises (Figure 1, 558). Much of the student text abundantly involve descriptions of learning experiences such as: "The teacher is lecturing, students are listening to him at their seats" (S82, grade 6, boy); "The teacher is writing questions and students are solving" (S101, grade 7, boy); or "The teacher lectures and asks questions, the student answers. Whiteboard and desks are used" (S5, grade 8 , boy). One of the students wrote: "An ordinary mathematics class (boring)" (S13, grade 8, boy).

In general, the physical setup of student desks indicated the traditional lecture form consisting of rows of seating. In many depictions, students face the

\section{Figure 2}

Examples of Student Drawings and Texts of the Mathematics Classroom

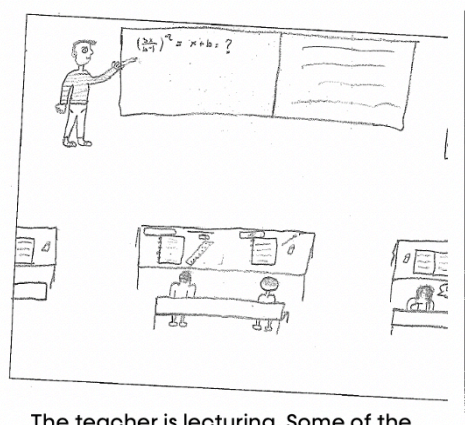

The teacher is lecturing. Some of the students are listening, some are not. We use notebook, pencil, eraser and our brains. ( $(19$, grade 8 , boy)

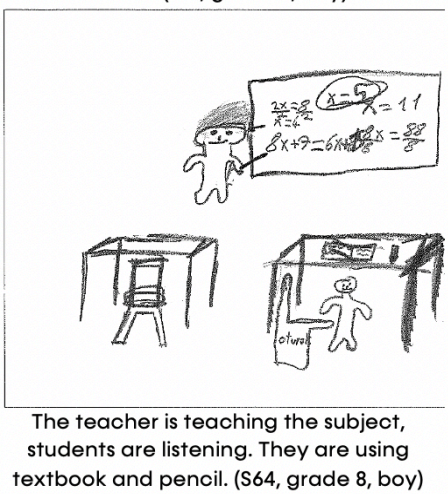

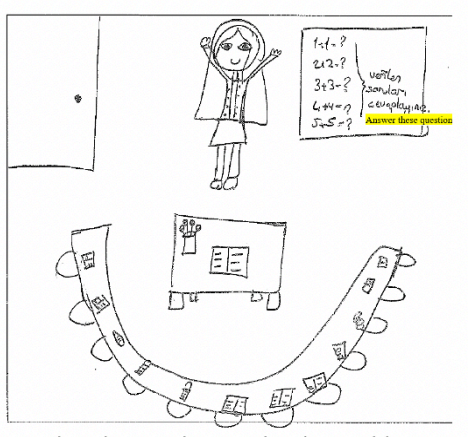

In the picture, the teacher is teaching. Children are listening. (\$63, grade 7 , girl)

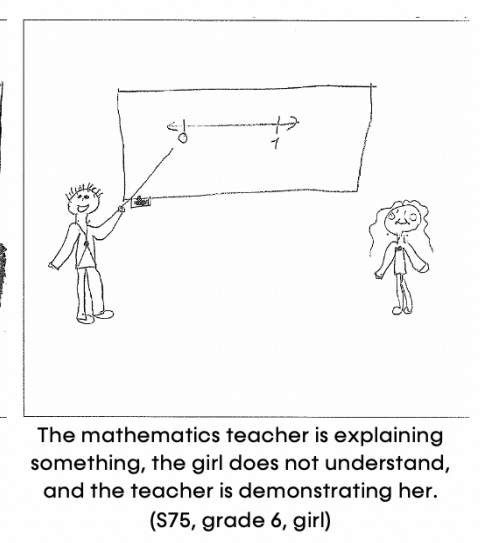




\section{iejee $\approx$}

teacher with their backs to one another (Figure 1, S58) indicating no student-student interaction. Also, none of the student text included descriptions indicating any interactions among students, or between students and the teacher while working on an activity collectively. In about $55 \%$ of drawings there is one student sitting at the desk. In several cases students were depicted at the whiteboard (Figure 2, S75). In approximately $37 \%$ of other drawings, more than one student is shown, and all are sitting in rows (Figure 2, S19). Sometimes this configuration is suggested by the drawing of classroom furniture (Figure 1, S43). In about $7 \%$ of pictures $(n=8)$, the semi-circle setup where students face each other while the teacher is lecturing is depicted, but even in these drawings no descriptions accompanying these depictions indicate student-student interaction (Figure 2, S63).

\section{Teaching Resources}

There was little indication of alternative teaching materials such as technological or digital tools, concrete manipulatives, or videos in student drawings. While in a few responses a computer $(n=1)$ or smartboard $(n=7)$ was mentioned, in the majority of responses (97\%), standard classroom materials such as a whiteboard, notebooks, textbooks, pencils (in a few cases an eraser and ruler) were depicted or mentioned as materials used by the teacher and students. In a few responses, the students described their picture as: "Notebook and pencil are enough" (S27, grade 8, boy); or "Materials are not required much" (S23, grade 8, boy), indicating that students did not view manipulatives and technological or digital

\section{Table 3}

The Nature of Mathematical Tasks Depicted in Drawings

\begin{tabular}{|c|c|c|}
\hline Nature of the task & Frequency & Example \\
\hline Practice questions & $37(31.6 \%)$ & $\begin{array}{l}\sqrt{100}=? \text { ? }(S 2, \text { grade } 8, \text { girl) } \\
\text { What is the square of } 7 / 9 \text { ? (S71, grade } 7, \text { boy) } \\
\sqrt{ }(4+x)=?(S 96, \text { grade } 7, \text { girl) } \\
2^{\times}=3,8^{\times}=?(S 14, \text { grade } 8, \text { boy }) \\
2 / 3+1 / 3=? 2, \overline{5}=\text { ? (S91, grade } 7, \text { girl) }\end{array}$ \\
\hline Basic operations & $15(12.8 \%)$ & $\begin{array}{l}2+2=4(\text { S3, grade } 8, \text { girl }) \\
2 \times 2=4(\text { S77, grade 6, boy })\end{array}$ \\
\hline Numerical equations & $14(12 \%)$ & $\begin{array}{l}2.2 .2=2^{3}=8 \quad(S 24, \text { grade } 8, \text { boy }) \\
5^{-3}=1 / 125 \quad 6^{-3}=1 / 243 \quad(S 57, \text { grade } 8, \text { boy })\end{array}$ \\
\hline Algebraic expressions & $9(7.7 \%)$ & $\begin{array}{l}a^{b} ; a^{-b}(S 31, \text { grade 8, girl) } \\
2 x+7(\text { (S94, grade 7, girl) }\end{array}$ \\
\hline Algebraic equations & $6(5.1 \%)$ & $\begin{array}{l}2 x+3 x=5 x(\text { S112, grade 8, girl }) \\
x+2=0(S 73, \text { grade } 7, \text { boy })\end{array}$ \\
\hline Numerical expressions & $6(5.1 \%)$ & $\begin{array}{l}4^{-5} ; 2.2 ; 2^{-3} \text { (S50, grade 8, boy) } \\
1,8 \overline{111} \ldots 1,9(\mathrm{~S} 92, \text { grade } 7, \text { girl) }\end{array}$ \\
\hline Scribbles (indicating practice questions) & $7(6 \%)$ & $\begin{array}{l}\text { [Scribbles on the whiteboard] The teacher } \\
\text { comes, writes a question on the board, then asks } \\
\text { a student to solve the question. (S49, grade } 8 \text {, girl) }\end{array}$ \\
\hline No indication & $23(19.7 \%)$ & --- \\
\hline
\end{tabular}

tools as instruments used in mathematics teaching and learning.

Among the whole group, while 23 responses (19.7\%) involved no mathematical work, 94 responses (80.3\%) included depictions or text of the mathematical work engaged in by the teacher and students. The mathematical tasks in many responses (about $31.6 \%$ ) consisted of performing standard algorithms with fractions, square roots, exponentials or solving algebraic expressions, or calculations of square roots or exponents (see Table 3). The pathway to a solution in these tasks is implied as they are routine exercises. The tasks do not seem to require the use of different strategies such as drawing a diagram, making a table, or guessing and testing, nor do they consist of additional contexts or meanings.

In the remaining responses, the mathematical work involved either the four basic mathematical operations (12.8\%) or a numerical/algebraic equation/ expression (about 30\%). The final group (6\%) indicated that the mathematical work was practicing questions. In this group, students usually scribbled on the whiteboard and described the mathematical activity as performing exercises such as: "After teaching the subject at the beginning and solving a few examples, our teacher is giving us questions and [we are] answering the questions" (S26, grade 8, boy). The given context in these responses is such that the focus of the questions could be determined to be procedural fluency, with students shown to be using procedures and algorithms to reproduce previously learned facts. To illustrate, in describing his picture, S115 
(grade 8, boy) stated: "The teacher is solving questions at the smart board. Always. All the time, always, until death". He depicted: "...+... =......................" and wrote: "[The teacher:] Let's perform this question". His visual and the written text describe a classroom context in which routine exercises appeared to be the only activity performed.

The form of representations in the depicted mathematical work is predominantly symbolic (72.6\%), mostly involving equations and expressions (Table 2). The mathematical work in three responses represents static pictures (visual): a number line (Figure 2, S75), a cube, and a set diagram and graph. In two drawings, verbal representations are evident. In one response the probability of certain events is mentioned: "Then 1 means certainty doesn't it? [the event will happen; its probability is 1]" (S117, grade 8, girl), and in another, the concept of square root is represented: "A quadratic number is the square of a number" (S56, grade 8, boy). The representation of tasks was not clear in the remaining responses as they were scribbles (6\%), or there was no reference to a mathematical task (19.7\%).

\section{Discussion}

The findings demonstrated that participant students perceived their mathematics classrooms as follows: mathematics classrooms are directed by the teacher wherein the teacher is at the center of instruction and learning; the teacher explains and demonstrates the subject and/or solves routine questions. Students sit at desks and listen to the teacher who stands in front of the class and lectures. The class mostly practices procedures, closed mathematics questions with one answer; working on open-ended questions or tasks is not that usual. The interaction between the teacher and students in the classroom is limited to asking and answering routine mathematics questions, while almost no content-related interactions among students occur. A whiteboard and notebooks/textbooks are the main teaching and learning materials. Mathematics is commonly represented through symbolic representations (numbers, equations, expressions).

The study findings support earlier results, which showed that Turkish lower secondary, or elementary (Turgut \& Turgut, 2020), school students perceive their mathematics classrooms as highly teacherdirected where students passively listen to the teacher who stands in front of the class and transmits facts, mathematical operations and procedures to students (Hatisaru, 2019b). The findings are also consistent with research internationally which have reported that many students associate mathematics predominantly with routine procedures or operations (Hatisaru, in press; Picker \& Berry, 2000; Rock \& Shaw, 2000; Ucar et al., 2010) and view learning of mathematics as an individual activity (Johansson \& Sumpter, 2010). Students generally perceive the types of work experienced in mathematics lessons as work that the student studies individually, solving problems from textbooks or given by the teacher, while the teacher teaches the whole class (Pehkonen et al., 2016). What is surprising in this study, however, is that there is no variation in student responses in terms of teaching and learning practices, and in teaching resources used in the classroom. Almost all of the 117 students depicted and described the same classroom experiences. In contrast to Rock and Shaw (2000), students in grades 6, 7 and 8 mentioned the same paper-based materials as tools of the teaching and learning mathematics rather than some alternative resources, and to Pehkonen et al. (2011), student pictures contained hardly any active learning practices such as thinking, speaking, or discussing. Although this was not an aspect of the data analysis, as opposed to findings in Laine et al. (2013), the kind of feelings in students' responses were relatively neutral ("They [students] are sitting. Listening to the teacher. The teacher is lecturing. It is important to use pencil and eraser" S57, grade 7 , boy), or in several instances rather negative (e.g., s13).

These findings are worrying for a few reasons. First, teaching practices that are characterized as traditional (direct teaching where students are being asked to memorise and apply facts and procedures) can negatively impact students' attitudes towards mathematics, resulting in students not remaining engaged and being successful in mathematics (Boaler, 2015; Swan, 2006; Smith \& Stein, 2011). This type of instruction may increase students' factual knowledge and their competency in solving routine problems, but they have no significant effect on students' reasoning skills (Bietenbeck, 2014; Swan, 2006; Vincent-Lancrin et al., 2019). If the descriptions of students in this study are typical, it is highly probable that Turkish students have many opportunities to practice procedures to become fluent in them. Rich discussions based on more openended problem-solving tasks, nevertheless, appear to be absent in the classroom teaching that many students experience.

Second, there is consistent evidence that students' perceptions of classroom learning environments are associated with their learning outcomes (Fraser, 2014) involving mathematics performance (Wong, Marton, Wong, \& Lam, 2002), and interest in (Latterell \& Wilson, 2012) and attitudes about (Hatisaru \& Murphy, 2019; Picker \& Berry, 2000) mathematics. The longterm learning outcomes of a student who described 
her mathematics classroom as: "The teacher is lecturing but in a boring way. Students listen to him and take notes. They really don't want to be taught mathematics. All are sad. The class is boring. All the teacher is doing is lecturing and giving examples. Very boring!" (S18, grade 8, girl); or who thought: "I don't understand anything in mathematics. She [the teacher] always gives us problems to solve without explaining properly. Most of the students don't understand. Pencil, notebook [are used]" (S9, grade 8, girl), would negatively be impacted by their reported classroom experiences.

The classroom learning environment created by teachers plays a significant role in shaping students' perceptions of school subjects and how new knowledge is created regarding those subjects (Picker \& Berry, 2000; Tsai, 2000). A possible explanation for participant students' perceptions might be that students regularly experience direct teaching practices in their mathematics lessons, like many other students across the world (Nistor, GrasVelazquez, Billon, \& Mihai, 2018; Vincent-Lancrin et al., 2019). The instructional practices, however, cannot be thought of in isolation to contextual factors (Anthony \& Walshaw, 2009; Kilpatrick et al., 2001). The preponderance of direct teaching practices may be specific to Turkey where students are placed in high schools and universities based on their nationwide multiple-choice standardized test scores. As their test scores determine which high school or university a student goes, students give much importance to mathematics (Hatisaru, 2020b) and practising test questions is important, even while they may not necessarily understand the questions (Ucar et al., 2010). Mathematics teachers utilize more direct instructional practices in the classroom in response to the students' needs (Altinyelken \& Sozeri, 2017; Nistor et al., 2018; Vincent-Lancrin et al., 2019) and use chiefly paper-based materials in their teaching in line with teacher-led instructions (Nistor et al., 2018). This trend unfortunately shows little variation with higher levels of teaching experience; that is, more years in teaching mathematics rarely means more variety in teaching methods (Nistor et al., 2018). There are concerns among mathematics educators that many students are successful in solving test questions, but they are not necessarily building mathematical understanding (Tunc-Pekkan, 2019).

The student response pattern of, not viewing technological tools and concrete manipulatives as tools found and used in mathematics classrooms could be their classroom realities. The current mathematics curriculum suggests teachers use manipulatives (e.g., number cards, base ten block, fraction tiles, or real-life models) and technology in introducing new concepts and assessments where applicable (MoNE, 2018). It is yet probable that the use of physical manipulatives and technological or digital tools were not regular classroom experiences of participant students (Nistor et al., 2018), perhaps because such teaching resources were unavailable to the teachers in participant schools (Erbilgin, 2017), or possibly that the teachers in participant schools had lack of knowledge or confidence in, or unfavorable beliefs about, incorporating varied technologies in their classroom teaching (Altinyelken \& Sozeri, 2017). In the absence of observational or interview data, the study is unable to confirm these possible explanations for relevant response patterns. However, student perceptions showed that engaging in experiential learning practices and developing technological and digital competences (MoNE, 2018) may not be classroom experiences for all students in Turkey.

Taken together, the results of this study suggest that if the goals of teaching mathematics are to help students to be mathematically literate and to understand mathematical concepts and use them in daily life, and to express mathematical reasoning in problem solving processes (MoNE, 2018), then students must be supported to develop these skills. One of the key policy priorities should be to investigate possible sources of students' mathematics classroom perceptions found in this study and take measures to improve them.

\section{Conclusion and Direction for Future Research}

The aim of this article was to investigate Turkish lower secondary students' perceptions of teaching and learning practices in mathematics classrooms. The students depicted mathematics teachers as transmitting information and demonstrating correct solutions while students are passive recipients. The drawings and associated texts, however, represent student responses at that point in time and within that classroom context. Other mathematical practices may exist but were not mentioned by the students so cannot be excluded. A second limitation relating to external validity also exists. It is not known whether the students' perceptions of mathematics classroom practices found in this study are the result of the specific characteristics of schools who participated in this study, or whether they are representative of a general trend in the population from which the sample has been drawn. Thus, the findings may not be generalizable to other schools in Ankara or to other regions in Turkey. Nevertheless, the findings presented here provide valid and valuable insight into mathematics classrooms and contain several implications. Together the drawing data and students' descriptions of pictures, strengthen the validity of the study and the conclusions drawn. 
The Draw a Mathematics Classroom Test and its coding schema have been developed based on an extensive literature review. Both instruments provide mathematics educators and researchers with a tool for obtaining and evaluating information on what classroom mathematics teaching look like from the student's perspective. Through their reflections on the research instrument, participant students have generated numerous insights into mathematical practices in schools in Turkey which has thrown up several questions in need of further investigations. First, in the current study, drawings as well as writing were used as a mechanism for collecting information from the study sample. Different results could be obtained using other forms of data generation, and I hope that other researchers would investigate that possibility. For instance, future studies involving classroom observations on the current topic could add to the understandings we have gained from the drawing task, and assist us to determine how their actual classroom experiences contribute to the development of student perceptions. Perceptions of phenomena are likely to differ according to the participants consulted within an environment (Beswick, 2007). That is, the teacher and individual students in a class may all have different conceptions of what goes on in the same learning environment (e.g., Kalyon, 2020). Second, teachers' conceptions of mathematics teaching and learning experiences are likely to be unique and hence worthy of future investigations. Most of the students in this study described their perceived classrooms in neutral statements, while several responses indicated that some of the students found their mathematics lessons "boring" (\$13, grade 8, boy). Finally, further investigations into what students' preferred mathematics classroom learning environments might look like, and associations between student perceptions of classroom practices and their learning outcomes (e.g., achievement, attitudes towards, or interest, in mathematics) is strongly recommended.

\section{Acknowledgements}

I am grateful to the schools and students for participating in this study. I thank Ismail Yolcu and Ebru Boynuegri for their assistance in data collection and coding, and Megan Quentin-Baxter and John Williamson for reading the manuscript and thoughtful conversations. I would also like to thank Nicoli Barnes for proofreading the manuscript.

\section{References}

Altinyelken, H. K., \& Sozeri, S. (2017). Assumptions and implications of adopting educational ideas from the west: The case of student-centered pedagogy in Turkey. In M. Akiba and G. LeTendre (Eds.), International Handbook of Teacher Quality and Policy (pp. 254-270). Routledge: New York.

Anthony, G., \& Walshaw, M. (2009). Effective pedagogy in mathematics. Educational Series 19. Brussels: International Academy of Education; Geneva: International Bureau of Education.

Australian Curriculum, Assessment and Reporting Authority [ACARA]. (2018). The Australian Curriculum: Mathematics. Retrieved from https://www.australiancurriculum.edu.au/f-10curriculum/mathematics/

Beswick, K. (2007). Teachers' beliefs that matter in secondary mathematics classrooms. Educational Studies in Mathematics, 65(1), 95120.

Bietenbeck, J. (2014). Teaching practices and cognitive skills. Labour Economics, 30, 143-153.

Boaler, J. (2015). What's math got to do with it? How teachers and parents can transform mathematics learning and inspire success. New York, New York: Penguin Books

Bobis, J., Anderson, J., Martin, A., \& Way, J. (2011). A model for mathematics instruction to enhance student motivation and engagement. In D. J. Brahier \& W. R. Speer (Eds.), Motivation and disposition: Pathways to learning, 73rd yearbook of the National Council of Teachers of Mathematics (pp. 1-12). Reston, VA: NCTM.

Bragg, L. (2007). Students' conflicting attitudes towards games as a vehicle for learning mathematics: A methodological dilemma. Mathematics Education Research Journal 19(1), 29-44.

Brown, L. (1992). The influence of teachers on children's image of mathematics. For the Learning of Mathematics, 12(2), 29-33.

Chambers, D. W. (1983). Stereotypic images of the scientist: The Draw-a-Scientist Test. Science Education, 67(2), 255-265. 


\section{iejee}

Elo, S., \& Kyngäs (2008). The qualitative content analysis process. Journal of Advanced Nursing 62(1), 107-115. https://doi.org/10.1111/j.13652648.2007.04569.x

Erbilgin, E. (2017). A comparison of the mathematical processes embedded in the content standards of Turkey and Singapore. Research in Social Sciences and Technology, 2(1), 53-74.

European Schoolnet (2018). Science, technology, engineering and mathematics education policies in Europe. Scientix observatory report. October 2018, European Schoolnet, Brussels.

Evans, I. M., Harvey, S. T., Bucley, L., \& Yan, E. (2009). Differentiating classroom climate concepts: Academic, management, and emotional environments. New Zealand Journal of Social Sciences, 4(2), 131-146. https://doi.org/10.1080/11 $77083 \times .2009 .9522449$

Fraser, B. (2014). Classroom learning environments: Historical and contemporary perspectives. In N. G. Lederman \& S. K. Abell (Eds), Handbook of Research on Science Education Volume II (pp. 104-119). USA: Routledge.

Finson, K. D. (2002) Drawing a scientist: What we do and do not know after fifty years of drawings. School Science and Mathematics, 102(7), 335345.

Gulek, C. (1999). Using multiple means of inquiry to gain insight into classrooms: A multi-trait multimethod approach (Unpublished doctoral dissertation). Boston College, Chestnut Hill, the USA.

Haney, W., Russel, M., \& Bebell, D. (2004). Drawing on education: Using drawings to document schooling and support change. Harvard Educational Review, 74(3), 241-271.

Harris, L. R., Harnett, J. A., \& Brown, G. (2009). "Drawing" out student conceptions: Using pupils' pictures to examine their conceptions of assessment. In D. M. Mclnerney, G. T. L. Brown, \& G. A. D. Liem (Eds.), Students perspectives on assessment: What students can tell us about assessment for learning (pp. 53-83). Charlotte, NC: Information age publishing, Inc.

Hatisaru, V. (2019a). Lower secondary students' views about mathematicians depicted as mathematics teachers. LUMAT: International Journal on Math, Science and Technology Education, 7(2), 27-49. https://doi.org/10.31129/ LUMAT.7.2.355
Hatisaru, V. (2019b). Putting the spotlight on mathematics classrooms. In J. Novotná \& H. Moraová (Eds.), Proceedings of the International Symposium Elementary Mathematics Teaching (SEMT), (pp. 182-192). ISBN 9788076030695.

Hatisaru, V. (2020a). Exploring evidence of mathematical tasks and representations in the drawings of middle school students. International Electronic Journal of Mathematics Education, 15(3), 1-21.

Hatisaru, V. (2020b). Perceived need for mathematics among lower secondary students. Australian Mathematics Education Journal, 2(1), 9-14.

Hatisaru, V. (in press). "[He] has impaired vision due to overworking": Students' views about mathematicians. In C. Andrà, D. Brunetto \& F. Martignone (Eds.), Views and Beliefs in Mathematics Education. Switzerland: Springer.

Hatisaru, V., \& Murphy, C. (2019). 'Creature' teachers 'monster' mathematicians: students' views about mathematicians and their stated attitudes to mathematics. International Journal of Education in Mathematics, Science and Technology, 7(3), 215-221.

Johansson, D. A., \& Sumpter, L. (2010). Childrens' conceptions about mathematics and mathematics education. In K. Kislenko (Ed.), Proceedings of the MAVI-16 conference June 26-29, 2010 (pp. 77-88). Tallinn, Estonia: Tallinn University of Applied Sciences.

Johnson, E. L. (2018). A New Look at the Representations for Mathematical Concepts: Expanding on Lesh's Model of Representations of Mathematical Concepts. Forum Public Policy Online 11.

Kalyon, D. S. (2020). Primary teachers' and students' images of teachers and learning environments. International Electronic Journal of Elementary Education, 13(1), 155-167.

Kearney, K. S., \& Hyle, A. E. (2004). Drawing out emotions: The use of participant-produced drawings in qualitative inquiry. Qualitative Research, 4(3), 361-382.

Kilpatrick, J., Swafford, J., \& Findell, B. (Eds.). (2001). Adding it up: Helping children learn mathematics. National Academy Press. 
Laine, A., Näveri, L., Ahtee, M., Hannula, M. S., \& Pehkonen, E. (2013). Emotional atmosphere in third graders' mathematics classroom: An analysis of pupils' drawings. Nordic Studies in Mathematics Education, 17(3-4), 101-116.

Laine, A., Ahtee, M., \& Näveri, L. (2020). Impact of teachers' actions on emotional atmosphere in mathematics lessons in primary school. International Journal of Science and Mathematics Education, 18, 163-181. https://doi. org/10.1007/s10763-018-09948-x

Lane, C., Stynes, M., \& O'Donoghue, J. (2014). The image of mathematics held by Irish postprimary students. International Journal of Mathematical Education in Science and Technology, 45(6), 879-891. https://doi.org/10.108 0/0020739X.2014.884648

Latterell, C. M., \& Wilson, J. L. (2012). Students' perceptions of what mathematicians do. The Mathematics Educator, 13(2), 73-84.

Lesh R., Post, T., \& Behr, M. (1987). Representations and translations among representations in mathematics learning and problem solving. In C. Janvier (Ed.), Problems of Representation in the Teaching and Learning of Mathematics (pp. 33-40) Hillsdale, NJ: Lawrence Erlbaum Associates.

Losh, S. C., Wilke, R., \& Pop, M. (2008). Some methodological issues with "Draw a Scientist Tests" among young children. International Journal of Science Education, 30(6), 773-792.

Markovits, Z., \& Forgasz, H. (2017). 'Mathematics is like a lion': Elementary students' beliefs about mathematics. Educational Studies in Mathematics, 96, 49-64. https://doi.org/10.1007/ s10649-017-9759-2

McHugh, M. L. (2012). Interrater reliability: The kappa statistic. Biochemia Medica, 22(3), 276-282.

Ministry of National Education (2018). Mathematics curriculum (Primary and Lower Secondary School Grades 1 to 8). Retrieved from http:// mufredat.meb.gov.tr/

Mullis, I. V. S., Martin, M. O., \& Loveless, T. (2016). 20 Years of TIMSS. International trends in mathematics and science achievement, curriculum, and instruction. Retrieved from http://timssandpirls. bc.edu/timss2015/international-results/
Mullis, I. V. S., Martin, M. O., Foy, P., \& Hooper, M. (2016). TIMSS 2015 international results in mathematics. Retrieved from http://timssandpirls.bc.edu/ timss2015/international-results/

Murphy, P. K., Delli, L. A. M., \& Edwards, M. N. (2004). The good teacher and good teaching. Comparing the beliefs of second-grade students, preservice teachers, and inservice teachers. The Journal of Experimental Education, 72(2), 69-92.

National Council of Teachers of Mathematics (2014). Principles to actions: Ensuring mathematical success for all. Reston VA: Author.

National Governors Association Center for Best Practices \& Council of Chief State School Officers. (2010). Common core state standards for mathematics. Washington, DC: Author. Retrieved from http://www.corestandards.org

Nesin, A. (2014, August). Too late for 2023, perhaps 2073 ! Gorus, 85, 24-26.

Nistor, A., Gras-Velazquez, A., Billon, N., \& Mihai, G. (2018). Science, technology, engineering and mathematics education practices in Europe. Scientix Observatory Report. December 2018, European Schoolnet, Brussels.

Pehkonen, E., Ahtee, M., \& Laine, A. (2016). Pupils' drawings as a research tool in mathematical problem-solving lessons. In P. Felmer, E. Pehkonen, \& J. Kilpatrick (Eds.), Posing and solving mathematical problems: Advances and new perspectives (Research in mathematics education) (pp. 167-188). Cham, Switzerland: Springer.

Pehkonen, E., Ahtee, M., Tikkanen, P., \& Laine, A. (2011). Pupils' conceptions on mathematics lessons revealed via their drawings. In B. Rösken \& $M$. Casper (Eds.), Current state of research on mathematical beliefs (pp. 182-191). Bochum, Germany: University of Bochum.

Picker, S., \& Berry, J., (2000). Investigating pupils' images of mathematicians. Educational Studies in Mathematics, 43, 65-94.

Remesal, A. (2009). Accessing primary pupils' conceptions of daily classroom assessment practices. In D. M. Mclnerney, G. T. L. Brown, \& G. A. D. Liem (Eds.), Students perspectives on assessment: What students can tell us about assessment for learning (pp. 25-51). Charlotte, NC: Information age publishing, Inc. 


\section{iejee $\approx$}

Rock, D., \& Shaw, J. M. (2000). Exploring children's thinking about mathematicians and their work. Teaching Children Mathematics, 6(9), 550-555.

Sam, L. C., \& Ernest, P. (2000). A survey of public images of mathematics. Research in Mathematics Education, 2(1), 193-206. https:// doi.org/10.1080/14794800008520076

Saunders, B., Sim, J., Kingstone, T., Baker, S., Waterfield, J., Bartlam, B., ... Jinks, C. (2017). Saturation in qualitative research: Exploring its conceptualization and operationalization. Quality and Quantity, 52, 1893-1907. https://doi. org/10.1007/s11135-017-0574-8

Smith, M. S., \& Stein, M. K. (2011). Five practices for orchestrating productive mathematics discussions. Reston, VA: NCTM.

Stiles, D. A., Adkisson, J. L., Sebben, D., \& Tamashiro, R. (2008). Pictures of hearts and daggers: Emotions are expressed in young adolescents' drawings of their attitudes towards mathematics. World Cultures eJournal, 16(2).

Sullivan, P. (2011). Teaching mathematics: Using research-informed strategies. Australian Council for Educational Research.

Swan, M. (2005). Improving learning in mathematics: Challenges and strategies. Department of Education and Skills Standards Unity.

Swan, M. (2006). Learning GCSE mathematics through discussion: What are the effects on students? Journal of Further and Higher Education, 30(3), 229-241.

Thomas, J. A., Pedersen, J. E., \& Finson, K. (2001). Validating the Draw-A-Science-Teacher-Test Checklist: Exploring mental models and teacher beliefs. Journal of Science Teacher Education, 12(4), 295-310.

Tsai, C. C. (2000). Relationships between student scientific epistemological beliefs and perceptions of constructivist learning environments. Educational Research, 42(2), 193205. https://doi.org/10.1080/001318800363836

Turgut, S., \& Turgut I. G. (2020). Me while I am learning mathematics: Reflections to elementary school students' drawings. International Electronic Journal of Elementary Education, 13(1), 139-154.
Tunc-Pekkan, Z. (2019, December 13). Milli korkumuz matematik. Sozcu. Retrived from https://www. sozcu.com.tr

Ucar, Z., Piskin, M., Akkas, E., \& Tascl, D. (2010). Elementary students' beliefs about mathematics, mathematics teachers and mathematicians. Education and Science, 35(155), 131-144.

Vieluf S., Kaplan, D., Klieme, E., \& Bayer, S. (2012). Teaching practices and pedagogical innovation: Evidence from TALIS. OECD Publishing.

Vincent-Lancrin, S., Urgel, J., Kar, S., \& Jacotin, G. (2019). Measuring innovation in education 2019: What has changed in the classroom? Educational Research and Innovation, OECD Publishing, Paris. https://doi.org/10.1787/9789264311671-en

Wong, N. Y., Marton, F., Wong, K. M., \& Lam, C. C. (2002). The lived space of mathematics learning. Journal of Mathematical Behavior, 21, 25-47. 